\title{
Description and Taxonomic Status of Cytophaga heparina (Payza and Korn) comb. nov. (Basionym: Flavobacterium heparinum Payza and Korn 1956)
}

\begin{abstract}
PENELOPE CHRISTENSEN
Department of Microbiology, University of Alberta, Edmonton, Alberta T6G 2E9, Canada

Flavobacterium heparinum was inadequately characterized when it was originally described by Payza and Korn in 1956. As a result it was listed as a species incertae sedis in the 8th edition of Bergey's Manual. The authors isolated a single strain of this organism, and presumably it was this strain which was deposited in the American Type Culture Collection (ATCC) under the number 13125 (= National Collection of Industrial Bacteria [NCIB] 9290). Because the original description was based on a single strain, ATCC 13125 is here regarded as the type strain of $F$. heparinum by monotypy. The results of an extensive study of the morphological, physiological, biochemical, and antimicrobial (lytic) properties of this strain suggest that it is more properly classified in the genus Cytophaga as $C$. heparina (Payza and Korn) comb. nov.
\end{abstract}

Very little is known about the organism described in 1956 by Payza and Korn as Flavobacterium heparinum $(6,7)$ beyond its ability to degrade heparin, which it can use as a sole carbon and nitrogen source (9). The organism's enzymes have been useful in the study of the structure of heparin (3). The study reported here was undertaken to update the description of this organism and to determine its proper taxonomic niche.

\section{MATERIALS AND METHODS}

Bacterial strains. A culture of American Type Culture Collection (ATCC) strain 13125 (= National Collection of Industrial Bacteria [NCIB] 9290) of Flavobacterium heparinum was obtained from NCIB. The control organisms used were obtained from NCIB, ATCC, and F.D. Cook $(1,2)$.

Methods. The methods used have been described previously $(1,2)$.

\section{RESULTS}

The characteristics of strain NCIB 9290 were found to be as follows.

Cell morphology. Gram-negative, nonflagellated, flexible rods'(Fig. 1), 0.3 by 1.0 to $9.0 \mu \mathrm{m}$, showing gliding motility and limited ability to spread on certain media.

Cultural characteristics. On Cook cytophaga agar, 5-day-old colonies were deep yellowgray (Munsell color: 2.5 Y 7/4), irregular, smooth to rough, lobate, umbonate, and transparent with no water-soluble pigment.

On skim milk-acetate agar, 5-day-old colonies were yellowish-orange-gray (Munsell color: 10 YR 7/4), irregular, smooth to rough, lobate, umbonate, and translucent with no water-soluble pigment.
On plate count agar, 5-day-old colonies were yellowish-orange-gray (Munsell color: 10 YR 6/4), more or less circular, smooth, entire, umbonate, and translucent with no water-soluble pigment.

The Munsell color of colonies on various media ranges from 10 YR 6-7/4-6 and also 2.5 YR 7/4; no water-soluble pigment has ever been observed.

In overnight-shaken broth culture, the growth is slightly silky, but not viscous or flocculent; no surface ring or pellicle is produced.

Neither fruiting bodies nor microcysts are produced.

Physiology. Growth was not reduced by up to $3 \% \mathrm{NaCl}$; the preferred atmosphere was air or $10 \% \mathrm{O}_{2}$; the temperature range was 10 to $30^{\circ} \mathrm{C}$; optimum growth occurred at 20 to $35^{\circ} \mathrm{C}$; the $\mathrm{pH}$ range was 7 to 10 ; optimum growth also occurred at $\mathbf{p H} 7$ to 10 .

Utilizes $\mathrm{NH}_{4}^{+}$, urea, asparaginate, and some proteins and protein digests (e.g., tryptone, casein), but not $\mathrm{NO}_{3}{ }^{-}$, glutamate, or certain other proteins and protein digests (e.g., gelatin, milk, Casitone) as sole $\mathrm{N}$ sources.

Growth was stimulated by yeast extract.

Growth was reduced by $0.01 \%$ and inhibited by $0.1 \%$ sodium lauryl sulfate. Susceptible to 300 $\mathrm{U}$ of polymyxin $\mathrm{B}$ and to actinomycin $\mathrm{D}$. Resistant to $30 \mu \mathrm{g}$ of chloramphenicol, $10 \mu \mathrm{g}$ of dihydrostreptomycin, and to $10 \mathrm{U}$ of penicillin.

Except for one actinomycete (UASM 4432) and possibly another (UASM 4441), bacteria and fungi were not lysed; a chlorella was also possibly lysed.

Biochemical reactions. Attack on glucose was both oxidative and slowly fermentative. 


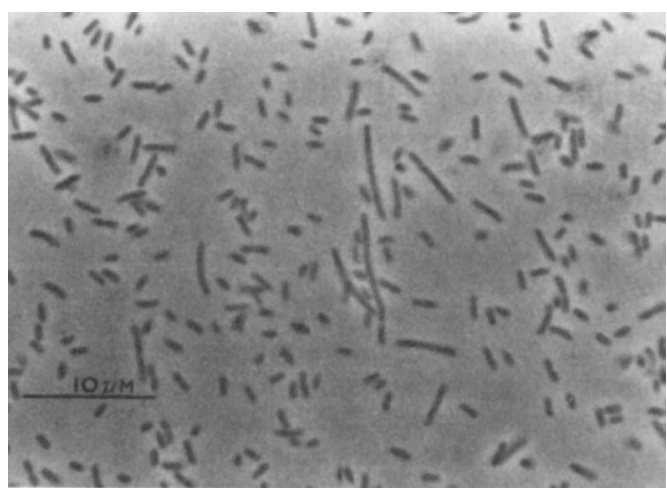

Fig. 1. Cells of strain NCIB 9290.

Acid was produced from cellobiose, sucrose, lactose, glucose, mannitol, and glycerol (slow).

Lipolytic on Tweens $20,40,60$, and 80.

Starch, cellulose (filter paper or carboxymethyl cellulose), chitin, agar, pectate, and alginate were not hydrolyzed.

Gelatin was not liquefied and milk was not peptonized; growth occurred in Casitone broth; growth and $\mathrm{NH}_{3}$ were produced from casein and slowly from Casamino broths. The organism grew on $0.2 \%$ tryptone agar and hemolyzed sheep erythrocytes in 7 but not in 2 days.

$\mathrm{H}_{2} \mathrm{~S}$, catalase, oxidase, and phosphatase were produced; the indole-methyl red-Voges-Proskauer-citrate tests were negative; no growth occured on McConkey or eosin methylene blue agar. Did not reduce $\mathrm{NO}_{3}{ }^{-}$or $\mathrm{NO}_{2}{ }^{-}$to gaseous form. Deoxyribonuclease was not produced.

\section{DISCUSSION}

The name Flavobacterium heparinum Payza and Korn is validly published and legitimate (4, 9), but since so little was known about this organism, Weeks relegated it to the species incertae sedis section of Flavobacterium in the 8th edition of Bergey's Manual (9). There is no indication that Payza and Korn isolated more than one strain of $F$. heparinum, and it is assumed that the organism deposited with the ATCC by Korn under the number 13125 (= NCIB 9290) is the isolate on which the original description of $F$. heparinum was based. The identification of this strain has been verified by the ATCC, and this strain is here regarded as the type strain of Flavobacterium heparinum by monotypy. ATCC 13125 was used by Dietrich (3) for studies of heparin structure, and it is the strain used in the present study, having been obtained from NCIB as 9290 . The organism has been shown to glide $(5,8)$, and it degrades heparin, a mucopolysaccharide acid composed of hexosamine and hexuronic acid units containing sulfuric acid ester groups. Heparin has the properties of a polymer and is an anticoagulant produced by mast and liver cells. Nonfruiting gliding organisms which have a low guanine plus cytosine $(\mathrm{G}+\mathrm{C})$ content in their deoxyribonucleic acids and which degrade polysaccharides are placed in the genus Cytophaga (5) of the order Cytophagales. This investigation confirms the gliding motility of and presents further data on the organism, none of which specifically excludes it from the genus Cytophaga.

However the $\mathrm{G}+\mathrm{C}$ value of this organism, which has recently been revised upwards to 45.6 $\mathrm{mol} \%$ (8) from its originally quoted value of 42.2 $\mathrm{mol} \%$ (5), poses a problem. The range of the $\mathrm{G}+\mathrm{C}$ contents of species accepted into the genus Cytophaga in the latest edition of Bergey's Manual (9) is 33 to $42 \mathrm{~mol} \%$. NCIB 9290 is clearly outside this already wide range for one genus, but if one then considers the $\mathrm{G}+\mathrm{C}$ contents of the deoxyribonucleic acids of other polysaccharolytic species which also seem to belong to $C y$ tophaga (Table 1), then the range is extended to 32.5 to $48.7 \mathrm{~mol} \%$. It is fairly obvious that this "Cytophaga group" is still a heterogeneous mix-

TABLE 1. Known $G+C$ contents of the deoxyribonucleic acids of polysaccharolytic cytophagas and putative cytophagas

\begin{tabular}{|c|c|}
\hline Organisms & $\begin{array}{c}\mathrm{G}+\mathrm{C} \\
\text { content } \\
\text { (mol\%) }\end{array}$ \\
\hline \multicolumn{2}{|l|}{ Marine species } \\
\hline \multicolumn{2}{|l|}{ Agarolytic } \\
\hline Cytophaga lytica & $33.2-34.2$ \\
\hline C. latercula & 34.2 \\
\hline C. diffluens & $34.7-42.3$ \\
\hline \multicolumn{2}{|l|}{ Amylolytic } \\
\hline C. fermentans & 39 \\
\hline \multicolumn{2}{|l|}{ Cellulolytic $^{a}$} \\
\hline Microscilla arenaria & 32.5 \\
\hline$M$. aggregans & $36.5-39.5$ \\
\hline$M$. sericea & $38-39$ \\
\hline$M$. furvescens & 44 \\
\hline \multicolumn{2}{|l|}{ Soil and freshwater species } \\
\hline \multicolumn{2}{|l|}{ Chitinolytic } \\
\hline C. johnsonae ${ }^{b}$ & $32.7-35$ \\
\hline Flexibacter sp. FS-1 & 48.7 \\
\hline \multicolumn{2}{|l|}{ Agarolytic } \\
\hline C. flevensis & 34.9 \\
\hline \multicolumn{2}{|l|}{ Cellulolytic $^{a}$} \\
\hline C. hutchinsonii & 39 \\
\hline $\begin{array}{l}\text { F. flexilis subsp. } \\
\text { pelliculosus }\end{array}$ & 39.5 \\
\hline C. aurantiaca & 42 \\
\hline F. sancti & $46-47$ \\
\hline
\end{tabular}

${ }^{a}$ Degradation of filter paper or carboxymethyl cellulose or both.

${ }^{b}$ Includes Flavobacterium pectinovorum (1). 
ture of organisms. When other organisms are described and more comparative studies are done, a basis for intelligent subdivision of the group may become apparent.

At present there is still an inadequate separation of Cytophaga from Flexibacter, which has a similar, wide $\mathrm{G}+\mathrm{C}$ range (29.8 to 47.5 mol\%). It is the author's opinion that there are not enough data on which to subdivide either of these genera any further. Those forms having any polysaccharase at all should be assigned to the genus Cytophaga until our knowledge permits the eventual redistribution of this group of gliding, nonsheathed, and nonhelical organisms into better defined, more restricted genera. Hence, it is suggested that the organism described here be removed from the genus Flavobacterium and be assigned to the genus Cytophaga as Cytophaga heparina (Payza and Korn) comb. nov. because it differs significantly from any of the presently described Cytophaga species.

\section{ACKNOWLEDGMENTS}

I thank F. D. Cook for his advice and encouragement and the National Research Council of Canada for financial assistance.

\section{LITERATURE CITED}

1. Christensen, P. J. 1977. Synonymy of Flavobacterium pectinovorum Dorey with Cytophaga johnsonae Stanier. Int. J. Syst. Bacteriol. 27:122-132.

2. Christensen, P. J., and F. D. Cook. 1978. Lysobacter, a new genus of nonfruiting, gliding bacteria with a high base ratio. Int. J. Syst. Bacteriol. 28:367-393.

3. Dietrich, C. P. 1969. Enzymic degradation of heparin. A sulphamidase and a sulphoesterase from Flavobacter. ium heparinum. Biochem. J. 111:91-95.

4. Hatt, H. D., and E. Zvirbulis. 1967. Status of names of bacterial taxa not evaluated in Index Bergeyana (1966). 1. Names published circa 1950-1967 exclusive of the genus Salmonella. Int. J. Syst. Bacteriol. 17:171-225.

5. Mitchell, T. G., M. S. Hendrie, and J. M. Shewan. 1969. The taxonomy, differentiation and identification of Cytophaga species. J. Appl. Bacteriol. 32:40-50.

6. Payza, A. N., and E. D. Korn. 1956. The degradation of heparin by bacterial enzymes. J. Biol. Chem. 223:853864.

7. Payza, A. N., and E. D. Korn. 1956. Bacterial degradation of heparin. Nature (London) 177:88-89.

8. Perry, L. B. 1973. Gliding motility in some non-spreading flexibacteria. J. Appl. Bacteriol. 36:227-232.

9. Weeks, O. B. 1974. Genus Flavobacterium, p. 357-364. In R. E. Buchanan, and N. E. Gibbons (ed.). Bergey's manual of determinative bacteriology, 8th ed. Williams and Wilkins, Baltimore. 